\title{
Spatial and temporal variations in the photosynthesis-nitrogen relationship in a Japanese cedar (Cryptomeria japonica D. Don) canopy
}

\author{
H. KOBAYASHI ${ }^{*, * * *,+}$, S. INOUE ${ }^{* *, \#}$, and K. GYOKUSEN ${ }^{* *}$ \\ Research Institute of Kyushu University Forests, Fukuoka 811-2415, Japan ${ }^{*}$ \\ Graduate School of Bioresource and Bioenvironmental Sciences, Kyushu University, Fukuoka 812-8581, Japan ${ }^{* *}$
}

\begin{abstract}
Spatial and temporal variations in light-saturated photosynthetic capacity and needle nitrogen $(\mathrm{N})$ content were investigated in one $8 \mathrm{~m}$ tall Japanese cedar (Cryptomeria japonica D. Don) canopy for a full year. The photosynthetic capacity and needle $\mathrm{N}$ content in various layers of the canopy were measured every month. Temporal variations in photosynthetic capacity and needle $\mathrm{N}$ content expressed on a projected-area basis $\left(\mathrm{P}_{\text {area }}, \mathrm{N}_{\text {area }}\right)$ were similar. Furthermore, both $\mathrm{P}_{\text {area }}$ and $\mathrm{N}_{\text {area }}$ decreased with increasing depth from the top of the canopy on each sampling date. As a consequence, a significant correlation was observed between $\mathrm{N}_{\text {area }}$ and $\mathrm{P}_{\text {area }}$. Temporal variations in photosynthetic capacity and needle $\mathrm{N}$ content expressed on a mass basis $\left(\mathrm{P}_{\text {mass }}, \mathrm{N}_{\text {mass }}\right.$ ) were also similar. $\mathrm{P}_{\text {mass }}$ also decreased with increasing canopy depth. However, in contrast to $\mathrm{N}_{\text {area }}$, there was only a slight decrease in $\mathrm{N}_{\text {mass }}$ with increasing canopy depth. Hence, the correlation between $\mathrm{N}_{\text {mass }}$ and $\mathrm{P}_{\text {mass }}$ was lower than the projected-area value. Because $\mathrm{N}_{\text {area }}$ was highly correlated with the needle mass per projected-area (NMA), the spatial variation in $\mathrm{N}_{\text {area }}$ (and therefore $\mathrm{P}_{\text {area }}$ ) in the canopy is attributed to the variation in NMA, which decreases as the depth from the top of the canopy increases. Furthermore, the slope of the linear regression between $\mathrm{N}_{\text {area }}$ and NMA differed between sampling dates, indicating that the temporal variations in $\mathrm{N}_{\text {area }}$ (and therefore $\mathrm{P}_{\text {area }}$ ) are strongly influenced by $\mathrm{N}_{\text {mass }}$. For most of the sampling dates, a linear regression between $\mathrm{N}_{\text {area }}$ and $\mathrm{P}_{\text {area }}$ tends to converge into a single line segment. However, on several sampling dates, there was a pronounced decline in $\mathrm{P}_{\text {area }}$ below this line segment. This reduction in $\mathrm{P}_{\text {area, }}$, which does not accompany a reduction in $\mathrm{N}_{\text {area }}$, seems to be attributable to stomatal limitations induced by the low soil temperature in winter and early spring.
\end{abstract}

\section{Introduction}

Japanese cedar (Cryptomeria japonica D. Don) is one of the most well-represented plantation species in Japan. The planting area of this tree exceeds $40 \%$ of the total plantation area in Japan. Recently, carbon dioxide $\left(\mathrm{CO}_{2}\right)$ absorption by young plantations has attracted attention due to apprehension about the increasing $\mathrm{CO}_{2}$ concentration in the atmosphere, and the need for a precise evaluation of the amount of $\mathrm{CO}_{2}$ sequestered by young plantations.

In a wide variety of plants, light-saturated photosynthetic capacity is positively correlated with leaf nitrogen (N) content (Field and Mooney 1986). This relationship is based on the fact that the main carboxylating enzyme of plants, Rubisco, makes up a significant fraction of the total amount of $\mathrm{N}$ in the leaves (Evans 1989). The correlation is independent of the source of variation in leaf $\mathrm{N}$ content, whether it is light (DeJong and Doyle 1985, Hirose et al. 1988, Ellsworth and Reich 1993), nutrient availability (Gulmon and Chu 1981, Walters and Reich 1989, Rosati et al. 1999), leaf age (Hikosaka et al. 1994), or season (Reich et al. 1991). Therefore, leaf $\mathrm{N}$ is expected to be an effective index for modeling canopy photosynthesis from a single canopy scale (Leuning et al. 1991, Hollinger 1996) to a stand canopy scale (Koike et al. 2001) and furthermore, to a terrestrial ecosystem scale (Schulze et al. 1994).

Many studies have reported a correlation between photosynthetic capacity and needle $\mathrm{N}$ content in evergreen conifers. In these studies, light (Bond et al. 1999, Palmroth and Hari 2001, Kobayashi and Gyokusen 2002, Han et al. 2003a), nutrient availability (Reich and Schoettle 1988, Marshall et al. 1994, Kobayashi and

Received 30 April 2008, accepted 26 April 2010.

${ }^{+}$Corresponding author; fax: +81-265-76-1533, e-mail: kobaafc@shinshu-u.ac.jp

${ }^{* * * *}$ Present address: Education and Research Center of Alpine Field Science, Shinshu University, 8304 Minamiminowa-mura, Nagano 399-4598, Japan.

"Present address: Tsukuba Research Institute, Sumitomo Forestry CO., LTD., 300-2646 Tsukuba, Japan.

Acknowledgements: The authors wish to thank the staff and students at the Research Institute of Kyushu University Forests for their kind support of our work. We also thank to two anonymous reviewers for helpful comments and improving the manuscript. 
Gyokusen 2002, Ripullone et al. 2003), and needle age (Brooks et al. 1996, Oleksyn et al. 1997, Schoettle and Smith 1999) were investigated as the source of variation in needle $\mathrm{N}$ content. However, each of these studies was conducted over a short period during a growing season under favorable conditions, and hence in evergreen conifers it remains unknown whether photosynthetic capacity correlates with needle $\mathrm{N}$ content considering the temporal changes in needles $\mathrm{N}$ content as the source of variation.

Evergreen species are photosynthetically active throughout the year under different environmental conditions. However, they do experience a reduction in photosynthesis due to droughts in the summer (Gyokusen

\section{Materials and methods}

Study site and plant material: Measurements were made at the arboretum of the Fukuoka Research Forest, a Kyushu University Forest located in Fukuoka, southwest Japan $\left(33^{\circ} 38^{\prime} \mathrm{N}, 130^{\circ} 31^{\prime} \mathrm{E}, 79 \mathrm{~m}\right.$ elevation). The climatic zone of this area is classified as warm-temperate. The mean annual air temperature and precipitation during the study period were $15.8^{\circ} \mathrm{C}$ and $1,250 \mathrm{~mm}$ in 2000 , and $15.7^{\circ} \mathrm{C}$ and $1,730 \mathrm{~mm}$ in 2001 , according to the annual report of the Kyushu University Forests for 2000 and 2001 (Fig. 1). A stand of C. japonica was used for this study. Trees were planted in five sequences of nine lines at intervals of $1.2 \mathrm{~m} \times 1.8 \mathrm{~m}$. The canopy was closed, and the mean tree height and the height of the lowest live branch were $8 \mathrm{~m}$ and $3 \mathrm{~m}$, respectively. The mean diameter at breast height was $11 \mathrm{~cm}$.

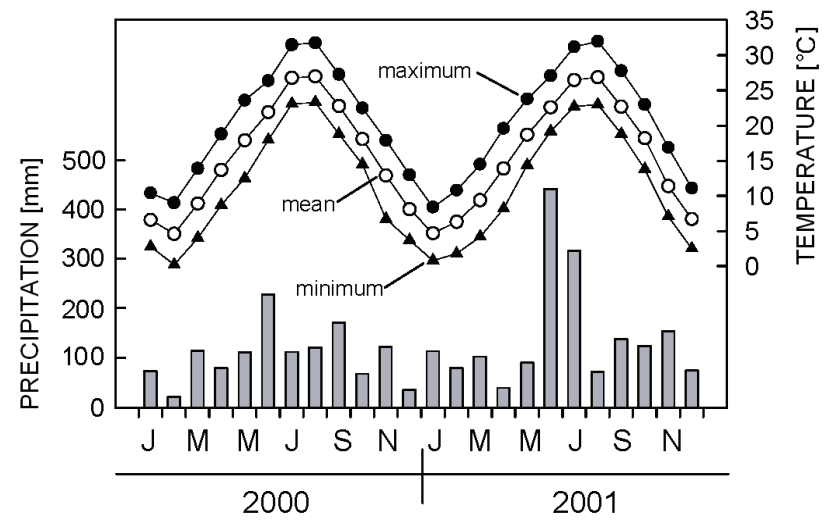

Fig. 1. Temporal variations in maximum $(\bullet)$, minimum $(\boldsymbol{\Delta})$, and mean (०) air temperature and precipitation (columns) at the experimental site during the two-year study period. Data were collected at the arboretum in the Fukuoka Research Forest of Kyushu University Forests.

Gas exchange measurements: Three trees of typical height and diameter were used for the measurements $(n=3)$. Scaffolding was erected to provide access to the canopy. The tree canopies were divided into six layers at and Suzaki 1990, Savé et al. 1999, Proietti and Famiani 2002) and low temperatures in the winter (Kume and Ino 1993, Schaberg et al. 1998, Miyazawa and Kikuzawa 2005). Since these reductions in photosynthesis are independent of any reduction in leaf $\mathrm{N}$ content, it is assumed that the photosynthesis- $\mathrm{N}$ relationship in evergreen species would vary greatly in the course of a year.

For this paper we investigated the light-saturated photosynthetic capacity and needle $\mathrm{N}$ content of a C. japonica canopy through a full year. The aim of our study was to clarify to what extent photosynthesis-N relationship would vary in $C$. japonica, when the season is considered as the source of the variation in needle $\mathrm{N}$ content.

equal intervals from the top to the bottom. One primary branch (a branch that diverges from the trunk) was selected from each canopy layer. The light-saturated rate of photosynthesis, stomatal conductance $\left(g_{\mathrm{s}}\right)$, and intercellular $\mathrm{CO}_{2}$ concentration in the needle space $\left(C_{\mathrm{i}}\right)$ of the current-year shoot was measured intact at the tip of each primary branch using a portable open gas exchange system ( $L C A-4, A D C$ BioScientific, Hoddesdon, UK). $C_{\mathrm{i}}$ was calculated from photosynthetic rate and $g_{\mathrm{s}}$ according to von Caemmerer and Farquhar (1981). Since there was no current-year shoot in the bottom layer of the canopy, the measurements were conducted in the five upper layers. The shoot in each canopy layer was measured from June 2000 to May 2001 at intervals of one month. Measurements were performed between 08:00 and 11:00 $\mathrm{h}$ over a photosynthetic photon flux density (PPFD) (400 to $700 \mathrm{~nm}$ ) $1,500 \mu \mathrm{mol} \mathrm{m} \mathrm{m}^{-2} \mathrm{~s}^{-1}$, at ambient $\mathrm{CO}_{2}$ concentration, air temperature, and relative humidity on clear or partly cloudy days.

Needle property measurements: After the gas exchange measurements, each shoot was excised from the branch. Needles were detached from the shoot and their projected area was measured with an image scanner (GT-5500, Epson, Suwa, Japan). Needles were then dried at $65^{\circ} \mathrm{C}$ for $48 \mathrm{~h}$. After determining dry weight needles were ground to a fine powder and then $\mathrm{N}$ concentration was determined with a CN-analyzer (MT-700, Yanaco, Kyoto, Japan).

Canopy light measurements: The PPFD was measured for each sampled shoot within a week after the gas exchange measurements. The PPFD was measured with a level quantum sensor (LI-190SA, Li-Cor, Lincoln, USA) and recorded with a $L i$-Cor data logger (LI-1400). A relative PPFD was calculated against the reference PPFD, measured simultaneously above the canopy. Measurements were taken from 10:00 $\mathrm{h}$ to $14: 00 \mathrm{~h}$ under an overcast sky. 
Statistical analyses: A two-way analysis of variance (ANOVA) was used to test the effects of spatial (canopy layer) and temporal (sampling date) variations on the light-saturated photosynthetic capacity and needle properties (needle $\mathrm{N}$ content and needle mass per projected area). Scheffé's multiple comparison tests were used to test the effect of temporal variations on $C_{\mathrm{i}}$ in the needle space. A linear regression was performed with photosynthetic capacity as a dependent variable against the needle properties. Differences in the slope and $y$ intercept of the linear regression between the sampling dates were tested by an analysis of covariance $(A N C O V A)$. All tests of significance were set at $P<0.05$. The statistical analyses were carried out using the STATISTICA 5.0J computer software package (StatSoft, Tulsa, USA).

\section{Results}

Relative PPFD (R-PPFD) in a $C$. japonica canopy decreased from June to September, then remained steady thereafter (Fig. 2). R-PPFD decreased with increasing depth from the top of the canopy ranging from maximum values of 0.83 to 0.53 in the uppermost layer of the canopy to lowest values of 0.16 to 0.07 in the fifth layer of the canopy.

The light-saturated photosynthetic capacity and needle properties differed significantly between canopy layers and sampling dates (Table 1).

Light-saturated photosynthetic capacity expressed on a projected-area $\left(\mathrm{P}_{\text {area }}\right)$ basis increased from June to October and then decreased gradually thereafter (Fig. 3A). Light-saturated photosynthetic capacity expressed on a mass basis $\left(\mathrm{P}_{\text {mass }}\right)$ remained steady from June to December, and then decreased rapidly thereafter (Fig. 3B). Both $\mathrm{P}_{\text {area }}$ and $\mathrm{P}_{\text {mass }}$ decreased with increasing

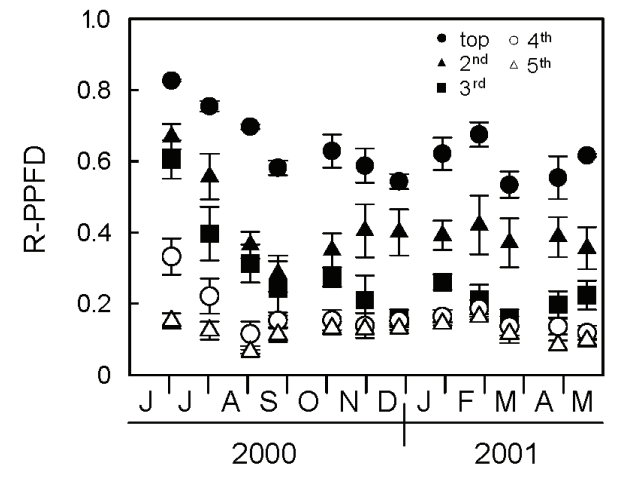

Fig. 2. Spatial and temporal variations in relative photosynthetic photon flux density (R-PPFD) in a Cryptomeria japonica canopy. Means and standard error of means $(n=3)$ are shown. $\bullet$, $\boldsymbol{\Delta}, \mathbf{\square}, \circ$, and represent the top, second, third, fourth, and fifth layer in the canopies, respectively.

Table 1. Results of two-way analysis of variance $(A N O V A)$ of light-saturated photosynthetic capacity and needle properties as a function of canopy layer and sampling. $\mathrm{P}_{\text {area }}$ and $\mathrm{P}_{\text {mass }}$ are light-saturated photosynthetic capacities expressed on a projected-area and mass basis, respectively. $\mathrm{N}_{\text {area }}$ and $\mathrm{N}_{\text {mass }}$ are needle nitrogen content expressed on a projected-area and mass basis, respectively. NMA is needle mass per projected area. $F$ values are presented. ${ }^{* * *} P<0.001,{ }^{*} P<0.01,{ }^{*} P<0.05$.

\begin{tabular}{llll}
\hline & Canopy layer & Sampling date & Interaction \\
\hline $\mathrm{P}_{\text {area }}\left[\mu \mathrm{mol}\left(\mathrm{CO}_{2}\right) \mathrm{m}^{-2} \mathrm{~s}^{-1}\right]$ & $108^{* * *}$ & $11.8^{* * *}$ & $1.58^{*}$ \\
$\mathrm{P}_{\text {mass }}\left[\mathrm{nmol}\left(\mathrm{CO}_{2}\right) \mathrm{g}^{-1} \mathrm{~s}^{-1}\right]$ & $50.8^{* * *}$ & $29.9^{* * *}$ & $1.80^{* *}$ \\
$\mathrm{~N}_{\text {area }}\left[\mathrm{g}(\mathrm{N}) \mathrm{m}^{-2}\right]$ & $59.3^{* * *}$ & $25.2^{* * *}$ & 0.93 \\
$\mathrm{~N}_{\text {mass }}\left[\mathrm{mg}_{\mathrm{N}} \mathrm{N} \mathrm{g}^{-1}\right]$ & $2.54^{*}$ & $60.4^{* * *}$ & 0.98 \\
$\mathrm{NMA}\left[\mathrm{g} \mathrm{m}^{-2}\right]$ & $82.8^{* * *}$ & $69.7^{* * *}$ & $1.58^{*}$ \\
\hline
\end{tabular}

depth from the top of the canopy. $\mathrm{P}_{\text {area }}$ was correlated with R-PPFD on each sampling date $(r=0.712 \sim 0.970)$. $\mathrm{P}_{\text {mass }}$ was also correlated with R-PPFD expect June and January $(r=0.410 \sim 0.951)$.

Needle $\mathrm{N}$ per projected area $\left(\mathrm{N}_{\text {area }}\right)$ increased from June to March and then decreased thereafter (Fig. 4A). $\mathrm{N}_{\text {area }}$ decreased with increasing depth from the top of the canopy and was correlated with R-PPFD on each sampling date $(r=0.676 \sim 0.958)$. $\mathrm{N}_{\text {mass }}$ remained steady from June to December and then decreased thereafter (Fig. $4 B$ ). In contrast to $\mathrm{N}_{\text {area }}$, there was only a slight decrease in $\mathrm{N}_{\text {mass }}$ with increasing depth from the top of the canopy. There was no significant correlation between R-PPFD and $\mathrm{N}_{\text {mass }}(r=0.001 \sim 0.481)$. Needle mass per projected-area (NMA) increased from June to March and then decreased thereafter. NMA also decreased with increasing depth from the top of the canopy and was correlated with R-PPFD on each sampling date $(r=$ 0.687 0.931).

$\mathrm{P}_{\text {area }}$ was significantly correlated with $\mathrm{N}_{\text {area }}$ on each sampling date except in June (Fig. 5A, Table 2). Although there was no significant difference between slopes $(F=1.68, P=0.082), A N C O V A$ did indicate a significant difference in the $y$-intercepts of the linear regression between sampling dates $(F=226.8, P<0.001)$. In contrast to $\mathrm{N}_{\text {area }}$, there was no significant correlation between $\mathrm{N}_{\text {mass }}$ and $\mathrm{P}_{\text {mass }}$ on each sampling date (Fig. 5B, Table 2). Although $\mathrm{P}_{\text {mass }}$ was significantly correlated with $\mathrm{N}_{\text {mass }}$ for all data pooled $(r=0.513)$, its correlation coefficient was low compared with that expressed on a projected-area 


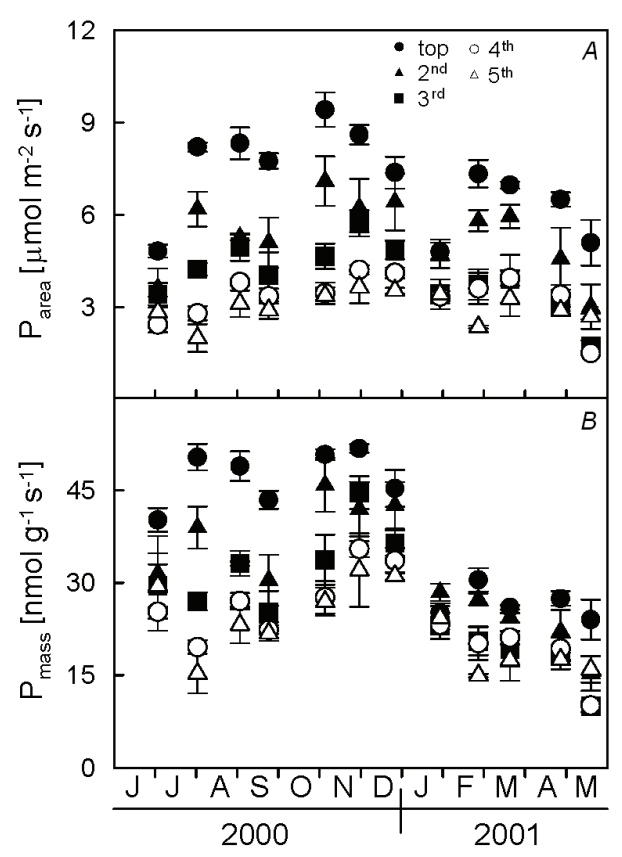

Fig. 3. Spatial and temporal variations in light-saturated photosynthetic capacity, expressed on a projected-area basis $\left(\mathrm{P}_{\text {area }}\right)(A)$ and mass basis $\left(\mathrm{P}_{\text {mass }}\right)(B)$. Means and standard error of means $(n=3)$ are shown. $\bullet, \mathbf{\Lambda}, \mathbf{\square}, \circ$, and represent the top, second, third, fourth, and fifth layer in the canopies, respectively.

basis $(r=0.655)$ (Table 2).

Both $\mathrm{P}_{\text {area }}$ and $\mathrm{N}_{\text {area }}$ were significantly correlated with NMA on each sampling date, except between NMA and $\mathrm{P}_{\text {area }}$ in June (Fig. 6A,B; Table 3). ANCOVA indicated significant differences in the slopes of the linear regressions between sampling dates $\left(\mathrm{P}_{\text {area }}\right.$ : $F=4.20$, $\left.P<0.001, \mathrm{~N}_{\text {area }}: F=7.07, P<0.001\right)$. Although $\mathrm{P}_{\text {area }}$ was significantly correlated with NMA for all data pooled $(r=0.409)$ (Table 3$)$, its correlation coefficient was low compared with that of leaf $\mathrm{N}$ content (Table 2).

$\mathrm{P}_{\text {area }}$ was highly correlated with stomatal conductance $\left(g_{\mathrm{s}}\right)$ on each sampling date $(r=0.862 \sim 0.980)$ (Fig. 7). Though $A N C O V A$ indicated a significant difference in the slope of the linear regression between sampling dates $(F=2.89, \quad P<0.01)$, the differences in the slope and

\section{Discussion}

Temporal variations in $\mathrm{P}_{\text {area }}$ and $\mathrm{N}_{\text {area }}$ were similar (Figs. $3 A$, 4A; Table 1). Furthermore, both $\mathrm{P}_{\text {area }}$ and $\mathrm{N}_{\text {area }}$ decreased with increasing depth from the top of the canopy on each sampling date. As a consequence, a significant correlation was observed between $\mathrm{N}_{\text {area }}$ and $\mathrm{P}_{\text {area }}$ (Fig. 5A, Table 2). Temporal variations in $\mathrm{P}_{\text {mass }}$ and $\mathrm{N}_{\text {mass }}$ were also similar (Figs. $3 B, 4 B$, Table 1). $\mathrm{P}_{\text {mass }}$ also decreased with increasing canopy depth. However, in contrast to $\mathrm{N}_{\text {area }}$, there was only a slight decrease in $\mathrm{N}_{\text {mass }}$ with increasing depth from the top of the canopy. Hence, the correlation between $\mathrm{P}_{\text {mass }}$ and $\mathrm{N}_{\text {mass }}$ was weaker

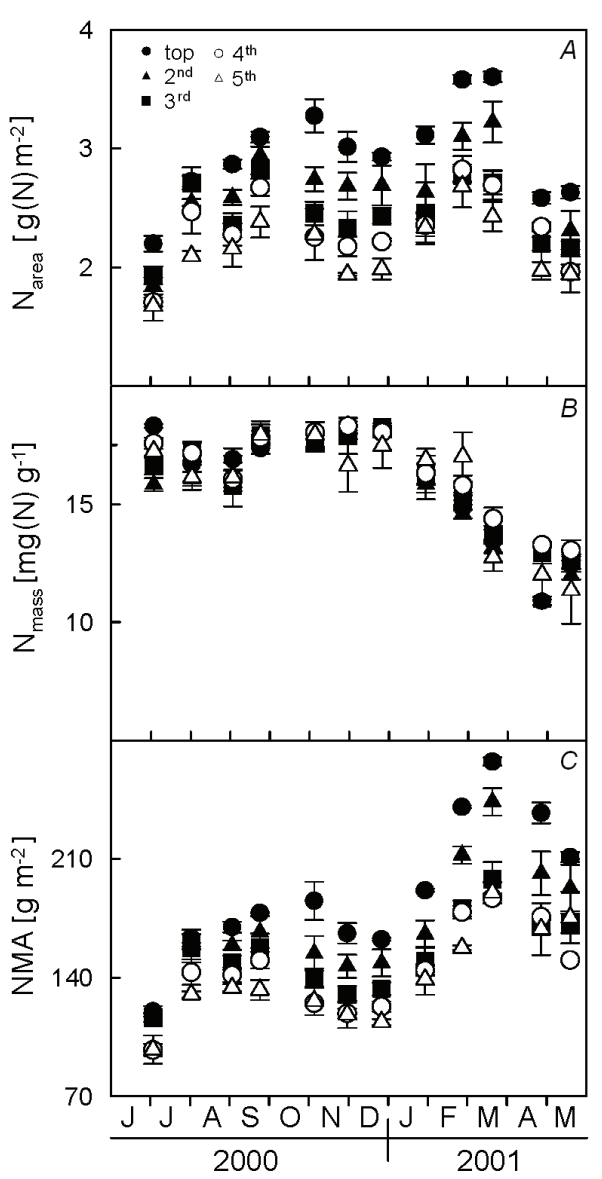

Fig. 4. Spatial and temporal variations in nitrogen content of needles, expressed on a projected-area basis $\left(\mathrm{N}_{\text {area }}\right)(A)$ and mass basis $\left(\mathrm{N}_{\text {mass }}\right)(B)$, and needle mass per projected-area (NMA) (C). Means and standard error of means $(n=3)$ are shown. $\bullet$, $\boldsymbol{\Delta}, \mathbf{\square}, \circ$, and represent the top, second, third, fourth, and fifth layer in the canopies, respectively.

the $y$-intercept were small.

$C_{\mathrm{i}}$ as a value relative to the atmospheric $\mathrm{CO}_{2}$ concentration $\left(C_{\mathrm{a}}\right)$ ranged between 0.6 and 0.7 for most of the sampling dates but fell to nearly 0.5 in February and March (Fig. 8). $C_{\mathrm{i}} / C_{\mathrm{a}}$ varied little within the canopy for most of the sampling dates (CV less than $10 \%$ ) but varied greatly in February and March (CV more than 20\%).

(Fig. 5B, Table 2). Because $\mathrm{N}_{\text {area }}$ was highly correlated with NMA on each sampling date (Fig. $6 B$, Table 3), the decrease in $\mathrm{N}_{\text {area }}$ and therefore $\mathrm{P}_{\text {area }}$ with increasing canopy depth is mainly due to the decrease in NMA, which decreases as the depth from the top of the canopy increases (Fig. 4C, Table 1). The slopes of the linear regressions between $\mathrm{N}_{\text {area }}$ and NMA differed between sampling dates. Since the slope of the linear regression between $\mathrm{N}_{\text {area }}$ and NMA represents $\mathrm{N}_{\text {mass }}$, this implies that

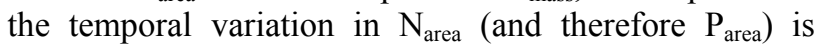
strongly influenced by $\mathrm{N}_{\text {mass }}$. 


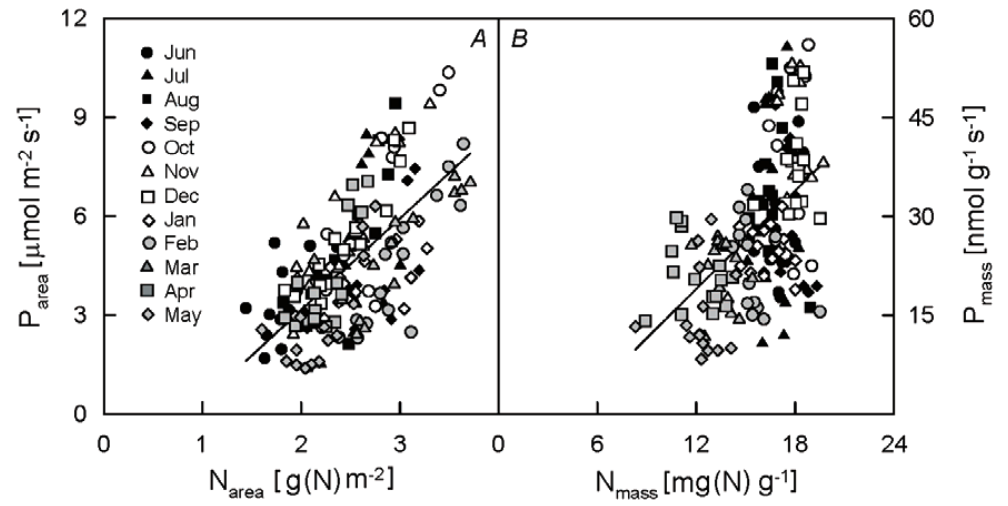

Fig. 5. Relationship between nitrogen content of needles and light-saturated photosynthetic capacity, expressed on a projected-area basis $\left(\mathrm{N}_{\text {area }}\right.$ and $\mathrm{P}_{\text {area }}$, respectively) $(A)$ and mass basis $\left(\mathrm{N}_{\text {mass }}\right.$ and $\mathrm{P}_{\text {mass }}$ respectively) $(B)$. The linear regression line for all data pooled is shown (see Table 2 for the linear regression line).

Table 2. Summary of linear regressions for light-saturated photosynthetic capacity versus needle $\mathrm{N}$ content on projected-area $\left(\mathrm{P}_{\text {area }} v s\right.$. $\mathrm{N}_{\text {area }}$ ) and mass $\left(\mathrm{P}_{\text {mass }} v s . \mathrm{N}_{\text {mass }}\right.$ ) basis, for various sampling dates. $\mathrm{P}_{\text {area }}$ and $\mathrm{P}_{\text {mass }}$ are light-saturated photosynthetic capacity expressed on a projected-area and mass basis, respectively. $\mathrm{N}_{\text {area }}$ and $\mathrm{N}_{\text {mass }}$ are needle nitrogen content expressed on a projected-area and mass basis, respectively. $* * * P<0.001, * * P<0.01, * P<0.05$. ns - not significant.

\begin{tabular}{llllrrr}
\hline Sampling date & \multicolumn{3}{l}{$\mathrm{P}_{\text {area }} v s . \mathrm{N}_{\text {area }}$} & \multicolumn{3}{l}{$\mathrm{P}_{\text {mass }} v s . \mathrm{N}_{\text {mass }}$} \\
& Slope & Intercept & $r$ & \multicolumn{1}{l}{ Slope } & Intercept & \multicolumn{1}{c}{$r$} \\
\hline $30^{\text {th }}$ June & 2.30 & -0.87 & $0.494^{\text {ns }}$ & 1.27 & 9.55 & $0.136^{\text {ns }}$ \\
$29^{\text {th }}$ July & 4.70 & -7.09 & $0.587^{*}$ & -1.51 & 55.34 & $-0.094^{\text {ns }}$ \\
$29^{\text {th }}$ August & 4.81 & -6.68 & $0.772^{* * *}$ & 0.76 & 20.73 & $0.087^{\text {ns }}$ \\
$19^{\text {th }}$ September & 4.25 & -7.19 & $0.720^{* *}$ & -6.10 & 136.83 & $-0.441^{\text {ns }}$ \\
$30^{\text {th }}$ October & 4.88 & -7.09 & $0.866^{* * *}$ & -0.27 & 41.85 & $-0.019^{\text {ns }}$ \\
$24^{\text {th }}$ November & 4.05 & -4.14 & $0.870^{* * *}$ & 3.35 & -18.67 & $0.453^{\text {ns }}$ \\
$20^{\text {th }}$ December & 4.16 & -4.93 & $0.921^{* * *}$ & 1.60 & 8.99 & $0.191^{\text {ns }}$ \\
$22^{\text {nd }}$ January & 1.57 & -0.10 & $0.712^{* *}$ & -0.35 & 30.58 & $-0.106^{\text {ns }}$ \\
$19^{\text {th }}$ February & 4.39 & -8.57 & $0.871^{* * *}$ & -2.30 & 58.36 & $-0.442^{\text {ns }}$ \\
$14^{\text {th }}$ March & 2.90 & -3.68 & $0.835^{* * *}$ & -0.93 & 34.23 & $-0.168^{\text {ns }}$ \\
$20^{\text {th }}$ April & 5.04 & -7.27 & $0.776^{* * *}$ & -0.74 & 29.82 & $-0.221^{\text {ns }}$ \\
$12^{\text {th }}$ May & 3.69 & -5.32 & $0.768^{* * *}$ & 0.50 & 8.97 & $0.104^{\text {ns }}$ \\
All data pooled & 2.77 & -2.39 & $0.655^{* * *}$ & 2.48 & -10.80 & $0.513^{* * *}$ \\
\hline
\end{tabular}

Table 3. Summary of linear regressions for light-saturated photosynthetic capacity and needle nitrogen content expressed on a projected-area basis versus needle mass per projected area, for various sampling dates. $\mathrm{P}_{\text {area }}$ and $\mathrm{N}_{\text {area }}$ are light-saturated photosynthetic capacity and needle nitrogen content, respectively, expressed on a projected-area basis. NMA is needle mass per projected-area. $* * * P<0.001, * * P<0.01, * P<0.05$. ns - not significant.

\begin{tabular}{lllllrl}
\hline Sampling date & \multicolumn{2}{l}{$\mathrm{P}_{\text {area }} v$. NMA } & \multicolumn{3}{c}{$\mathrm{N}_{\text {area }} v s$. NMA } \\
& Slope & Intercept & $r$ & Slope & Intercept & $r$ \\
\hline $30^{\text {th }}$ Jun & 0.040 & -0.94 & $0.470^{\text {ns }}$ & 0.0162 & 0.096 & $0.889^{* * *}$ \\
$29^{\text {th }}$ July & 0.108 & -11.60 & $0.719^{* *}$ & 0.0170 & -0.050 & $0.904^{* * *}$ \\
$29^{\text {th }}$ August & 0.123 & -13.36 & $0.902^{* * *}$ & 0.0193 & -0.463 & $0.886^{* * *}$ \\
$19^{\text {th }}$ September & 0.084 & -8.60 & $0.826^{* * *}$ & 0.0166 & 0.179 & $0.959^{* * *}$ \\
$30^{\text {th }}$ October & 0.082 & -6.41 & $0.869^{* * *}$ & 0.0162 & 0.228 & $0.968^{* * *}$ \\
$24^{\text {th }}$ November & 0.076 & -4.65 & $0.812^{* * *}$ & 0.0184 & -0.073 & $0.914^{* * *}$ \\
$20^{\text {th }}$ December & 0.082 & -5.96 & $0.936^{* * *}$ & 0.0188 & -0.111 & $0.964^{* * *}$ \\
$22^{\text {nd }}$ January & 0.033 & -1.31 & $0.807^{* * *}$ & 0.0173 & -0.153 & $0.925^{* * *}$ \\
$19^{\text {th }}$ February & 0.061 & -7.23 & $0.953^{* * *}$ & 0.0113 & 0.802 & $0.891^{* * *}$ \\
$14^{\text {th }}$ March & 0.043 & -4.45 & $0.896^{* * *}$ & 0.0128 & 0.142 & $0.936^{* * *}$ \\
$20^{\text {th }}$ April & 0.045 & -4.46 & $0.875^{* * *}$ & 0.0051 & 1.289 & $0.641^{* *}$ \\
$12^{\text {th }}$ May & 0.043 & -4.94 & $0.748^{* *}$ & 0.0087 & 0.639 & $0.725^{* *}$ \\
All data pooled & 0.022 & 1.06 & $0.409^{* * *}$ & & & \\
\hline
\end{tabular}




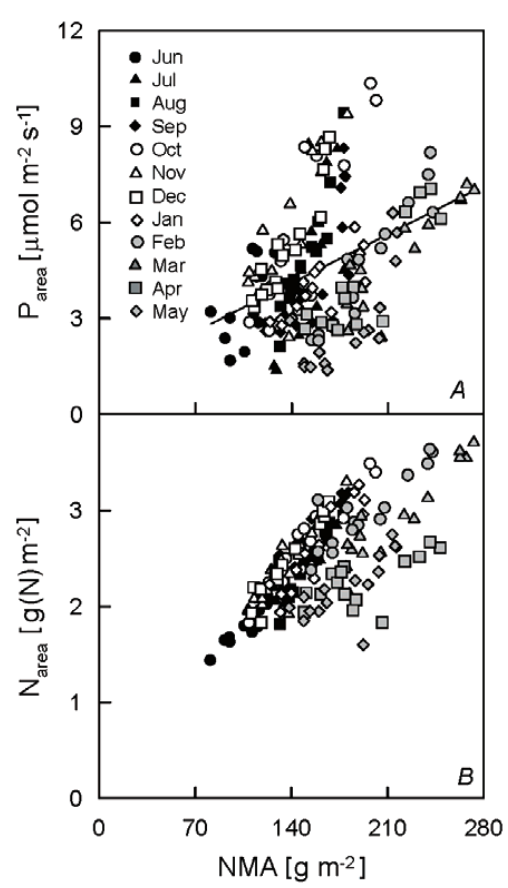

Fig. 6. Relationships between needles mass per projected-area (NMA) and light-saturated photosynthetic capacity $\left(\mathrm{P}_{\text {area }}\right)(A)$ and needle nitrogen content $\left(\mathrm{N}_{\text {area }}\right)(B)$, expressed on a projected-area basis. The linear regression line for all data pooled is shown (see Table 3 for the linear regression line).

In tree canopies, the factors affecting $\mathrm{N}_{\text {area }}$ depend on the source of variations in $\mathrm{N}_{\text {area }}$, whether it is light, season, or $\mathrm{N}$ availability. In particular, in tree canopies, there is usually a slight variation in $\mathrm{N}_{\text {mass }}$ with increasing canopy depth. Variations in $\mathrm{N}_{\text {area }}$ are mostly accounted for by the variation in NMA, which decreases markedly with decreasing light as the depth from the top of the canopy increases (DeJong and Doyle 1985, Ellsworth and Reich 1993, Kobayashi et al. 2000, Palmroth and Hari 2001). In contrast to the light environment, Reich et al. (1991) have shown that the temporal variation in $N_{\text {area }}$ is mostly affected by $\mathrm{N}_{\text {mass }}$ in deciduous tree canopies. Furthermore, many studies report that $\mathrm{N}_{\text {area }}$ is affected by $\mathrm{N}_{\text {mass }}$ when $\mathrm{N}$ availability is the source of variation in $\mathrm{N}_{\text {area }}$ (Kobayashi et al. 2000, Rosati et al. 2000, Ripullone et al. 2003). In a previous study, we reported that variations in $\mathrm{N}_{\text {area }}$ due to the light environment were affected by NMA in C. japonica saplings. In this study, we confirmed that this also holds in tall tree canopies of C. japonica. Moreover, our result has demonstrated that the temporal variation in $\mathrm{N}_{\text {area }}$ is affected by $\mathrm{N}_{\text {mass }}$ in C. japonica. $\mathrm{P}_{\text {area }}$ was highly correlated with $\mathrm{N}_{\text {area }}$ on each sampling date except in June (Fig. 5A, Table 2). In $C$. japonica shoot elongation begins from late April to early May and develops slowly, taking more than two months to mature (Itoh et al. 1989, Sakimoto and Hirayama 2002). We thus conclude that the shoots were not yet functionally developed in June and July and therefore high photosynthesis could not be attained. Once

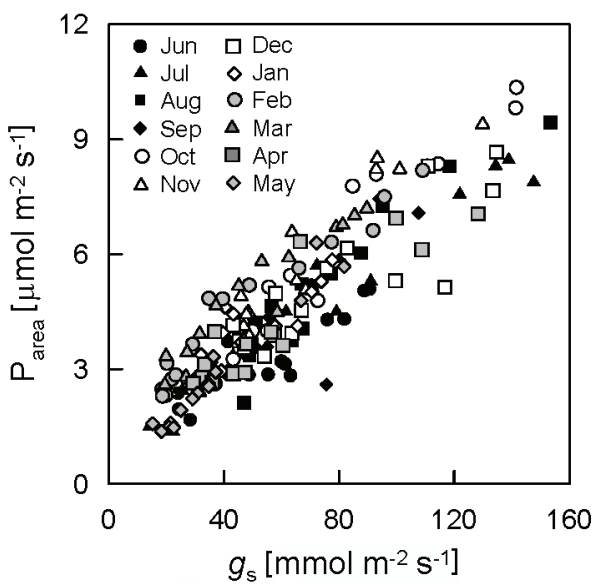

Fig. 7. Relationship between stomatal conductance $\left(g_{\mathrm{s}}\right)$ and light-saturated photosynthetic capacity $\left(\mathrm{P}_{\text {area }}\right)$.

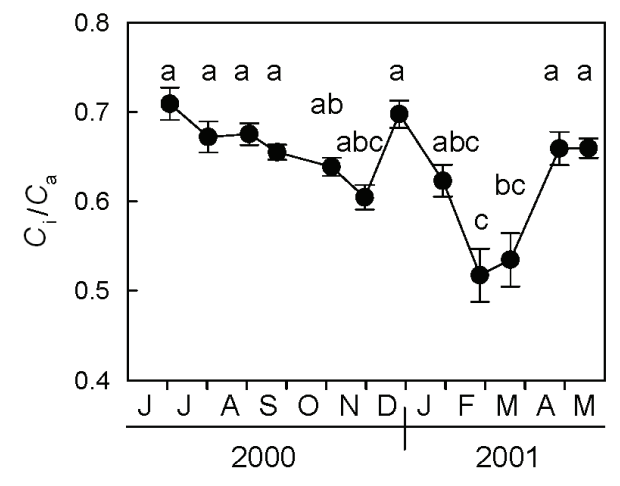

Fig. 8. Temporal variation in intercellular $\mathrm{CO}_{2}$ concentration in the needle space $\left(C_{\mathrm{i}}\right)$ relative to the atmospheric $\mathrm{CO}_{2}$ concentration $\left(C_{\mathrm{a}}\right)$. Means and the standard error of means $(n=15)$ are shown. Means denoted by different letters are significantly different at the $P<0.05$ level (Scheffé's multiple comparison test).

the shoots were functionally developed, i.e. after July, $\mathrm{P}_{\text {area }}$ was strongly influenced by $\mathrm{N}_{\text {area }}$ (Fig. $5 A$ ) and the stomatal conductance (Fig. 7). The linear regression between $\mathrm{P}_{\text {area }}$ and $\mathrm{N}_{\text {area }}$ tends to converge toward a single line segment in August, October, November, December and April. Data pooled for these five sampling dates yields a linear equation of $\mathrm{y}=-5.81+4.50 \mathrm{x}, r=0.843$, $P<0.001$, comparable to that for several boreal conifers $(\mathrm{y}=-1.50+4.07 \mathrm{x}$, Bond et al. 1999).

However, on some sampling dates (September, January, February, March, and May), there was a pronounced decline in linear regression lines below this line segment. These reductions in $\mathrm{P}_{\text {area }}$, which do not accompany reduction in $\mathrm{N}_{\text {area }}$, are attributed to either stomatal or non-stomatal limitations in $\mathrm{P}_{\text {area }}$. Due to inhibition of the potential for $\mathrm{CO}_{2}$ assimilation caused by low and chilling temperatures during winter, photoinhibition of PSII occurs in boreal conifers (Adams and Demmig-Adams 1994, Lundmark et al. 1998, Nippert et al. 2004) and Mediterranean sclerophyllous (Oliveria and 
Peñuelas 2000, 2001, Aranda et al. 2005). In C. japonica, it is also reported that the photochemical efficiency of PSII decreases in winter (Han and Mukai 1999, Han et al. 2003b). However, in the present study non-stomatal limitation does not seem to be the cause of any reduction in $\mathrm{P}_{\text {area }}$. There was a slight decrease in $C_{\mathrm{i}} / C_{\mathrm{a}}$ in January (Fig. 8), and hence a reduction in $\mathrm{P}_{\text {area }}$ on this sampling date would be attributed to stomatal limitation rather than nonstomatal limitation. Moreover, the significant decrease in $C_{\mathrm{i}} / C_{\mathrm{a}}$ in February and March indicates that the reduction in $\mathrm{P}_{\text {area }}$ on these sampling dates was strongly affected by stomatal closure in $C$. japonica. Due to cold soil and warm air temperatures in early spring, partial stomatal closure occurs in boreal conifers (Day et al. 1989, Day et al. 1991, Strand et al. 2002). The monthly minimum air temperature was below $5^{\circ} \mathrm{C}$ in February and March (Fig. 1), hence it may be assumed that low soil temperature induced stomatal closure in

\section{References}

Adams, W.W., Demming-Adams, B.: Carotenoid composition and down regulation of photosystem II in three conifer species during the winter. - Physiol. Plant. 92: 451-458, 1994.

Aranda, I., Castro, L., Alía, R., Pardos, J.A., Gil, L.: Low temperature during winter elicits differential responses among populations of the Mediterranean evergreen cork oak (Quercus suber). - Tree Physiol. 25: 1085-1090, 2005.

Bond, B.J., Farnsworth, B.T., Coulombe, R.A., Winner, W.E.: Foliage physiology and biochemistry in response to light gradients in conifers with varying shade tolerance. Oecologia 120: 183-192, 1999.

Brooks, J.R., Sprugel, D.G., Hinckley, T.M.: The effects of light acclimation during and after foliage expansion on photosynthesis of Abies amabilis foliage within the canopy. Oecologia 107: 21-32, 1996.

Day, T.A., DeLucia, E.H., Smith, W.K.: Influence of cold soil and snow cover on photosynthesis and leaf conductance in two Rocky Mountain conifers. - Oecologia 80: 546-552, 1989.

Day, T.A., Heckathorn, S.A., DeLucia, E.H.: Limitations of photosynthesis in Pinus taeda L. (Loblolly Pine) at low soil temperatures. - Plant Physiol. 96: 1246-1254, 1991.

DeJong, T.M., Doyle, J.F.: Seasonal relationships between leaf nitrogen content (photosynthetic capacity) and leaf canopy light exposure in peach (Prunus persica). - Plant Cell Environ. 8: 701-706, 1985.

Ellsworth, D.S., Reich, P.B.: Canopy structure and vertical patterns of photosynthesis and related leaf traits in a deciduous forest. - Oecologia 96: 169-178, 1993.

Evans, J.R.: Photosynthesis and nitrogen relationships in leaves of $\mathrm{C}_{3}$ plants. - Oecologia 78: 9-19, 1989.

Field, C., Mooney, H.A.: The photosynthesis-nitrogen relationship in wild plants. - In: Givnish, T.J. (ed.): On the Economy of Plant Form and Function. Pp. 25-55. Cambridge University Press, Cambridge - London - New York - New Rochelle - Melbourne - Sydney 1986.

Gulmon, S.L., Chu, C.C.: The effects of light and nitrogen on photosynthesis, leaf characteristics, and dry matter allocation in the chaparral shrub, Diplacus aurantiacus. - Oecologia 49: 207-212, 1981.
C. japonica on these sampling dates. We have no definite information as to why $\mathrm{P}_{\text {area }}$ declined in September and May. The sky was partly cloudy and clouds frequently interrupted the sunlight during both of these measurements. $\mathrm{P}_{\text {area }}$ may therefore have been underestimated due to insufficient light.

In conclusion, our data indicate that the photosynthesis- $\mathrm{N}$ relationship is more complex in evergreen conifers than in deciduous, where the correlation is independent of sampling date (Reich et al. 1991). There was a substantial reduction in $\mathrm{P}_{\text {area }}$ in winter and early spring, unaccompanied by any reduction in $\mathrm{N}_{\text {area }}$. This indicates that when measurements are made only in the growing season under favorable conditions, considerable overestimation of the annual carbon gain can occur. Frequent measurements are necessary to precisely evaluate the annual carbon gain in evergreen conifers in the warm-temperate zone.

Gyokusen, K., Suzaki, T.: [Diurnal changes of measured and simulated photosynthesis in Hinoki (Chamaecyparis obtusa Endl.) shoot.] - Bull. Kyushu Univ. Forest. ? 63: 55-69, 1990. [In Japan.]

Han, Q., Kawasaki, T., Katahata, S., Mukai, Y., Chiba, Y.: Horizontal and vertical variations in photosynthetic capacity in a Pinus densiflora crown in relation to leaf nitrogen allocation and acclimation to irradiance. - Tree Physiol. 23: 851-857, 2003a.

Han, Q., Mukai, Y.: Cold acclimation and photoinhibition of photosynthesis accompanied by needle color changes in Cryptomeria japonica during the winter. - J. Forest. $\mathbf{P}$ Res. 4: 229-234, 1999.

Han, Q., Shinohara, K., Kakubari, Y., Mukai, Y.: Photoprotective role of rhodoxanthin during cold acclimation in Cryptomeria japonica. - Plant Cell Environ. 26: 715-723, 2003 b.

Hikosaka, K., Terashima, I., Katoh, S.: Effects of leaf age, nitrogen nutrition and photon flux density on the distribution of nitrogen among leaves of a vine (Ipomoea tricolor Cav.) grown horizontally to avoid mutual shading of leaves. Oecologia 97: 451-457, 1994.

Hirose, T., Werger, M.J.A., Pons, T.L., van Rheenen, J.W.A.: Canopy structure and leaf nitrogen distribution in a stand of Lysimachia vulgaris L. as influenced by stand density. Oecologia 77: 145-150, 1988.

Hollinger, D.Y.: Optimality and nitrogen allocation in a tree canopy. - Tree Physiol. 16: 627-634, 1996.

Itoh, A., Yoshihara, M., Tamai, S.: [Shoot elongation characteristics of Cryptomeria japonica and Chamecyparis obtusa.] - Bull. Kyoto Univ. Forest. ? 61: 85-94, 1989. [In Japan.]

Kobayashi, H., Gyokusen, K.: [Effects of light and nitrogen fertilization on photosynthesis and leaf nitrogen content in Cryptomeria japonica sapling.] - J. Japan. Forest. ? Soc. 84: 180-183, 2002. [In Japan.]

Kobayashi, H., Gyokusen, K., Saito, A.: [Distribution of leaf nitrogen within sugi (Cryptomeria japonica D. Don) canopy growing at different positions on a slope.] - J. Japan. Forest. ? Soc. 82: 281-286, 2000. [In Japan.]

Koike, T., Kitao, M., Maruyama, Y., Mori, S., Lei, T.T.: Leaf 
morphology and photosynthetic adjustments among deciduous broad-leaved trees within the vertical canopy profile. - Tree Physiol. 21: 951-958, 2001.

Kume, A., Ino, Y.: Comparison of ecophysiological responses to heavy snow in two varieties of Aucuba japonica with different areas of distribution. - Ecol. Res. 8: 111-121, 1993.

Leuning, R., Wang, Y.P., Cromer, R.N.: Model simulations of spatial distributions and daily totals of photosynthesis in Eucalyptus grandis canopies. - Oecologia 88: 494-503, 1991.

Lundmark, T., Bergh, J., Strand, M., Koppel, A.: Seasonal variation of maximum photochemical efficiency in boreal Norway spruce stands. - Trees 13: 63-67, 1998.

Marshall, J.D., Dawson, T.E., Ehleringer, J.R.: Integrated nitrogen, carbon, and water relations of a xylem-tapping mistletoe following nitrogen fertilization of the host. Oecologia 100: 430-438, 1994.

Miyazawa, Y., Kikuzawa, K.: Winter photosynthesis by saplings of evergreen broad-leaved trees in a deciduous temperate forest. - New Phytologist 165: 857-866, 2005.

Nippert, J.B., Duursma, R.A., Marshall, J.D.: Seasonal variation in photosynthetic capacity of montane conifers. - Funct. Ecol. 18: 876-886, 2004.

Oleksyn, J., Tjoelker, M.G., Lorenc-Plucińska, G., Konwińska, A., Żytkowiak, R., Karolewski, P., Reich, P.B.: Needle $\mathrm{CO}_{2}$ exchange, structure and defense traits in relation to needle age in Pinus heldreichii Christ - a relict of Tertiary flora. - Trees 12: 82-89, 1997.

Oliveira, G., Peñuelas, J.: Comparative photochemical and phenomorphological responses to winter stress of an evergreen (Quercus ilex L.) and a semi-deciduous (Cistus albidus L.) Mediterranean woody species. - Acta Oecologia 21: 97-107, 2000

Oliveira, G., Peñuelas, J.: Allocation of absorbed light energy into photochemistry and dissipation in a semi-deciduous and an evergreen Mediterranean woody species during winter. Aust. J. Plant Physiol. 28: 471-180, 2001.

Palmroth, S., Hari, P.: Evaluation of the importance of acclimation of needle structure, photosynthesis, and respiration to available photosynthetically active radiation in a Scots pine canopy. - Can. J. For. Res. 31: 1235-1243, 2001.

Proietti, P., Famiani, F.: Diurnal and seasonal changes in photosynthetic characteristics in different olive (Olea europaea L.) cultivars. - Photosynthetica 40: 171-176, 2002.

Reich, P.B., Schoettle, A.W.: Role of phosphorus and nitrogen in photosynthetic and whole plant carbon gain and nutrient use efficiency in eastern white pine. - Oecologia 77: 25-33, 1988.

Reich, P.B., Walters, M.B., Ellsworth, D.S.: Leaf age and season influence the relationships between leaf nitrogen, leaf mass per area and photosynthesis in maple and oak trees. Plant Cell Environ. 14: 251-259, 1991.

Ripullone, F., Grassi, G., Lauteri, M., Borghetti, M.: Photosynthesis-nitrogen relationships: interpretation of different patterns between Pseudotsuga menziesii and Populus $\times$ euroamericana in a mini-stand experiment. - Tree Physiol. 23: 137-144, 2003.

Rosati, A., Day, K.R., DeJong, T.M.: Distribution of leaf mass per unit area and leaf nitrogen concentration determine partitioning of leaf nitrogen within tree canopies. - Tree Physiol. 20: 271-276, 2000.

Rosati, A., Esparza, G., DeJong, T.M., Pearcy, R.W.: Influence of canopy light environment and nitrogen availability on leaf photosynthetic characteristics and photosynthetic nitrogen-use efficiency of field-grown nectarine trees. - Tree Physiol. 19 : 173-180, 1999.

Sakimoto, M., Hirayama, K.: [Morphology, structure and dynamics of modules of Cryptomeria japonica saplings in canopy gaps and in closed canopy.] - Forest. $\checkmark$ ? Res. Kyoto 74: 53-58, 2002. [In Japan.]

Savé, R., Castell, C., Terradas, J.: Gas exchange and water relations. - In: Rodà, F., Retana, J., Gracia, C.A., Bellot, J. (ed.). Ecology of Mediterranean Evergreen Oak Forests. Ecological Studies: Analysis and Synthesis, Vol. Pp. 135-147. Springer-Verlag, Berlin 1999.

Schaberg, P.G., Shane, J.B., Cali, P.F., Donnelly, J.R., Strimbeck, G.R.: Photosynthetic capacity of red spruce during winter. - Tree Physiol. 18: 271-276, 1998.

Schoettle, A.W., Smith, W.K.: Interrelationships among light, photosynthesis and nitrogen in the crown of mature Pinus contorta ssp. latifolia. - Tree Physiol. 19: 13-22, 1999.

Schulze, E.-D., Kelliher, F.M., Körner, C., Lloyd, J., Leuning, R.: Relationships among maximum stomatal conductance, ecosystem surface conductance, carbon assimilation rate, and plant nitrogen nutrition: a global ecology scaling exercise. Annu. Rev. Ecol. Syst. 25: 629-660, 1994.

Strand, M., Lundmark, T., Söderbergh, I., Mellander, P.-E.: Impacts of seasonal air and soil temperatures on photosynthesis in Scots pine trees. - Tree Physiol. 22: 839847, 2002.

von Caemmerer, S., Farquhar, G..C.: Some relationships between the biochemistry of photosynthesis and the gas exchange of leaves. - Planta 153: 376-387, 1981.

Walters, M.B., Reich, P.B.: Response of Ulmus americana seedlings to varying nitrogen and water status. 1 Photosynthesis and growth. - Tree Physiol. 5: 159-172, 1989. 